\title{
Prosedur Perhitungan Dan Pelaporan Pajak Penghasilan (PPh) Pasal 21 Atas Gaji Pegawai Pada Pemerintah Kota Bitung
}

\author{
Oleh \\ Meilany Kesek \\ Herman Karamoy
}

\begin{abstract}
ABSTRAK
Selama ini pemerintah kota Bitung telah melakukan kewajiban sebagai pemotong PPh pasal 21, baik kewajiban pemotong masa maupun tahunan. Setiap bulan selama satu tahun, Pegawai Tetap Bulanan pemerintah kota Bitung mendapatkan penghasilan setiap bulan yang terdiri dari gaji pokok, tunjangan istri, tunjangan anak, tunjangan jabatan, asuransi tenaga kerja. Kebijakan dilakukan pemerintah kota Bitung, dalam menetapkan pemberian gaji pokok kepada pegawai adalah berdasarkan lama kerja pegawai, tingkat pendidikan dan tingkat jabatan yang diberikan. Berdasarkan hasil analisa dapat disimpulkan bahwa perhitungan dan pelaporan Pajak Penghasilan $(\mathrm{PPh})$ Pasal 21 yang di lakukan oleh pemerintah kota Bitung dengan perhitungan Pajak Penghasilan (PPh) Pasal 21 yang sesuai dengan Peraturan Perpajakan. Untuk itu prosedur perhitungan dan pelaporan yang dilakukan oleh pemerintah kota Bitung sudah sesuai dengan peraturan yang ada. Total penghitungan PPh pasal 21 Tahunan pemerintah kota Bitung selama satu tahun yang telah dipotong sebesar Rp 3,048,281,694 dari penghasilan pegawai kota Bitung. Pelaporan Pajak Penghasilan ( $\mathrm{PPh})$ Pasal 21 untuk SSP di laporkan selambat-lambatnya tanggal 10 bulan takwim, sedangkan untuk SPT masa di laporkan selambat-lambatnya tanggal 20 bulan takwim.
\end{abstract}

Kata Kunci: PPh Pasal 21

\begin{abstract}
ABSTRAC
During this Bitung city government has done duty as cutting income tax, either past or annual obligation cutter. Each month for one year, the city government employee Bitung Fixed Monthly earning every month which consists of basic salary, alimony, child support, alimony office, labor insurance. Bitung city government's policies, in establishing the provision of basic salary for employees are based on length of employment of employees, level of education and position level given. Based on the analysis it can be concluded that the calculation and reporting of Income Tax will be undertaken by the city of Bitung with the calculation of Income Tax in accordance with the Tax Regulations. For the calculation and reporting procedures are carried out by the municipality Bitung is in conformity with the existing regulations. The total tally Annual Income Tax Bitung city government for a year that has been cut by Rp 3,048,281,694 of income Bitung city employees .
\end{abstract}

Keywords : Income Tax 


\section{PENDAHULUAN}

\section{A. Latar Belakang Masalah}

Pajak merupakan iuran wajib yang diberlakukan pada setiap wajib pajak atas obyek pajak yang dimilikinya dan hasilnya diserahkan kepada pemerintah. Jenis pajak yang diberlakukan di Indonesia diantaranya adalah Pajak Penghasilan, Pajak Bumi dan Bangunan, Pajak Hiburan, Pajak Reklame, Pajak Hadiah dan lain-lain.

Pajak penghasilan merupakan pajak yang dipungut pada obyek pajak atas penghasilannya. Pajak penghasilan akan selalu dikenakan terhadap orang atau badan usaha yang memperoleh penghasilan di Indonesia. Pajak yang berlaku bagi pegawai/karyawan adalah pajak penghasilan pasal 21 . Undang-undang yang dipakai untuk mengatur besarnya tarif pajak, tata cara pembayaran dan pelaporan pajak adalah Undang-undang No.17 tahun 2000 yang merupakan penyempurnaan bagi undang-undang terdahulunya yaitu Undangundang No.10 tahun 1994. Undang-undang pajak penghasilan telah menetapkan sistem pemungutan pajak penghasilan secara self assessment, dimana wajib pajak diberi kepercayaan dan tanggung jawab penuh dari pemerintah untuk menghitung, membayar dan melaporkan sendiri jumlah pajak yang terhutang.Dengan sistem ini pemerintah berharap agar pelaksanaan pemungutan pajak penghasilan dapat berjalan dengan lebih mudah dan lancar.

Pada dasarnya pemerintah kota Bitung tersebut dalam menjalankan tugasnya tentu tidak dapat dilepaskan dari kewajiban-kewajiban pajak termasuk diantaranya untuk menghitung, memotong, menyetor, dan melaporkan Pajak Penghasilan (PPh) Pasal 21 yang terutang setiap bulan takwim. Hasil pemotongan pajak tersebut disetorkan ke Bank Persepsi atau Kantor Pos dan Giro dengan menggunakan Surat Setoran Pajak.Sedangkan pelaporan ke Kantor Pelayanan Pajak dilakukan dengan menggunakan Surat Pemberitahuan (SPT) Masa Pajak Penghasilan pasal 21.selain melakukan kewajiban bulanan, pemotong pajak pada akhir tahun pajak, diwajibkan untuk menghitung, menyetor dan melapor pajak yang terutang pada akhir tahun

Perumusan masalah yang dibuat dalam penyusunan laporan akhir ini, agar dalam proses penulisan dan pembahasan tidak melebar dan dapat difokuskan pada suatu pokok bahasan, maka dibuatkan suatu ruang lingkup yang meliputi :

1. Bagaimana perhitunganpajak penghasilan $(\mathrm{PPh})$ pasal 21 yang dilakukan oleh pemerintah kota Bitung atas gaji setiap pegawai yang ada pada setiap SKPD.

2. Apakah prosedur dan pelaporan pajak penghasilanpasal 21 pada Kantor Pemerintah Kota Bitung sudah sesuai dengan peraturan yang ada.

3. Bagaimana pemerintahkota Bitung Melakukan proses rekapitulasi pemasukan pajak penghasilan pasal 21 atas gaji pegawai yang sudah ditetapkan selama satu tahun.

\section{LANDASAN TEORI}

A. Pajak

Menurut, Prof. Dr. Rochmat Soemitro, SH ( 2006 ) pajak adalah iuran rakyat pada kas Negara berdasarkan undang-undang (yang dapat dipaksakan) dengan tiada dengan mendapatkan jasa timbale ( kontraprestasi ) yang langsung dapat ditunjukkan dan yang digunakan untuk membayar pengeluaran umum.

Dalam hal ini fungsi pajak dibagi atas dua bagian ( Mardiasmo,2006 : 2 ) yaitu :

1. Fungsi budgetair,

Pajak sebagai sumber dana bagi pemerintah untuk menbiayai pengeluaranpengeluarannya.

2. Fungsi mengatur

Pajak sebagai alat untuk mengatur atau melaksanakan kebijaksanaan pemerintah dalam bidang social dan ekonomi. 


\section{B. Pajak Penghasilan}

Pengertian penghasilan menurut Waluyo (2009:176) "penghasilan merupakan setiap tambahan kemampuan ekonomis yang diterima atau diperoleh wajib pajak atas seluruh penghasilannya." Pengertian penghasilan berdasarkan Kamus Istilah menurut Peraturan Perundang-undangan Republik Indonesia 1945-1998 (1999:418): Semua imbalan atau pembayaran dari pekerjaan dalam hubungan kerja yang dapat berupa upah, gaji, dan sebagainya, termasuk premi asuransi jiwa dan asuransi kesehatan yang dibayar oleh pemberi kerja. (penjelasan UU 7/1991 Ps.4(1)a.: TLN 1991/3459). Berdasarkan pengertian di atas, dapat disimpulkan bahwa penghasilan adalah perolehan atau kenaikan manfaat ekonomi dalam bentuk pemasukan atau penambahan aktiva atau penurunan kewajiban. Sedangkan Pajak Penghasilan (PPh) Pasal 21 adalah pajak atas penghasilan berupa gaji, upah, honorarium, tunjangan, dan pembayaran lain dengan nama apa pun yang diterima atau diperoleh Wajib Pajak orang pribadi dalam negeri sehubungan dengan pekerjaan/ jabatan, jasa, dan kegiatan.

\section{Tarif Pajak Dan Penerapannya}

Tarif pajak yang berlaku beserta penerapannya menurut ketentuan dalam pasal 21 undang-undang pajak penghasilan adalah sebagai berikut (Mardiasmo, 2006:156) :

1. Tarif berdasarkan pasal $17 \mathrm{UU} \mathrm{PPh}$, diterapkan atas penghasilan kena pajak dari :

a. Pegawai tetap

b. Penerima pensiun yang dibayarkan secara bulanan

c. Pegawai tidak tetap

d. Distributor perusahaan

2. Tarif berdasarkan pasal $17 \mathrm{UU} \mathrm{PPh}$, diterapkan atas penghasilan bruto berupa :

a. Honorarium, uang saku, hadiah atau penghargaan dengan nama dalam bentuk apapun.

b. Honorarium yang diterima atau diperoleh anggota dewan komisaris atau dewan pengawas yang tidak merangkap sebagai pegawai tetap pada perusahaan yang sama, selama satu tahun.

c. Jasa produksi

d. Penarikan dana pada dana pensiun yang pendiriannya telah disahkan oleh menteri keuangan.

3. Tarif sebesar $15 \%$, diterapkan atas perkiraan penghasilan neto yang dibayarkan atau terutang kepada tenaga ahli yang melakukan pekerjaan bebas. Besarnya penghasilan neto adalah $50 \%$ dari penghasilan bruto berupa honorarium atau imbalan lain dengan nama dalam bentuk apapun.

4. Tarif sebesar 5\% diterapkan atas upah harian, upah mingguan, upah satuan, upah borongan, dan uang saku harian yang jumlahnya melebihi Rp 110.000 sehari tetapi tidak melebihi Rp 1.100.000 dalam satu bulan atau dibayarkan secara bulanan.

Kemudian tarif pajak secara keseluruhan dibagi atas 4 bagian, yaitu :

a. Tarif sebanding/proposional, merupakan tarif berupa persentase yang tetap, terhadap berapapun jumlah yang dikenai pajak sehingga besarnya pajak yang terutang proposional terhadap besarnya nilai yang dikenai pajak.

b. Tarif tetap, tariff berupa jumlah yang tetap terhadap berapapun jumlah yang dikenai pajak sehingga besarnya pajak yang terutang tetap.

c. Tarif progresif, presentase tarif yang digunakan semakin besar bila jumlah yang dikenai pajak semakin besar.

d. Tarif degresif, presentse tarif yang digunakan semakin kecil bila jumlah yang dikenai pajak semakin besar.

\section{Surat pemberitahuan (SPT)}

Surat pemberitahuan (SPT) adalah surat yang oleh wajib pajak digunakan untuk melaporkan perhitungan dan pembayaran pajak, objek pajak dan bukan objek pajak atau harta 
dan kewajiban menurut ketentuan peraturan perundang-undangan perpajakan (Mardiasmo 2011:31).

Dalam hal ini fungsi SPT ( Mardiasmo 2006:26 ) adalah sebagai berikut

1. Fungsi SPT bagi wajib pajak penghasilan :

a. Sebagai sarana untuk melaporkan dan mempertanggungjawabkan perhitungan jumlah pajak yang sebenarnya terutang.

b. Untuk melaporkan pembayaran atau pelunasan pajak yang telah dilaksanakan sendiri atau melalui pemotong pajak atau pengumutan pajak lain dalam tahun pajak.

c. Untuk melaporkan pembayaran dari pemotong atau pemungut tentang pemotongan atau pengumutan pajak orang pribadi atau badan lain dalam satu masa pajak.

2. Fungsi SPT bagi pengusaha kena pajak :

a. Sebagai sarana untuk melaporkan dan mempertanggungjawabkan perhitungan jumlah pajak pertambahan nilai dan pajak penjualan atas barang mewah yang sebenarnya terutang.

b. Untuk melaporkan pengkreditan pajak masukan terhadap pajak keluaran.

c. Untuk melaporkan pembayaran atau pelunasan pajak yang telah dilaksanakan oleh pengusaha kena pajak atau melalui pihak lain dalam satu masa pajak.

3. Fungsi SPT bagi pemotong atau pemungut pajak

Sebagai sarana untuk melaporkan dan mempertanggungjawabkan pajak yang dipotong atau dipungut dan disetorkannya.

Prosedur penyelesaian surat pemberitahuan (SPT) yaitu :

a. Wajib pajak harus mengambil sendiri blangko SPT pada kantor pelayanan pajak setempat.

b. SPT harus diisikan dengan benar, jelas, lengkap sesuai dengan petunjuk yang diberikan.

c. Bukti-bukti harus dilampirkan pada SPT.

Adapun Prosedur Penerimaan Dan Pengolahan SPT Tahunan Pph Orang Pribadi :

Berdasarkan Peraturan Direktorat Dirjen Pajak No 19/PJ/2009 tentang tata cara penerimaan dan pengolahan Surat Pemberitahuan Tahunan (SPT Tahunan), standar tata cara penerimaan SPT Tahunan PPh adalah sebagai berikut :

1. Wajib Pajak menyampaikan SPT Tahunan/e-SPT Tahunan ke Kantor Pelayanan Pajak (KPP) dengan cara SPT dimasukkan ke dalam amplop tertutup yang telah ditulis dengan Nama Wajib Pajak, NPWP, Tahun Pajak, dan Status SPT (Nihil/Kurang Bayar/Lebih Bayar), serta Nomor telepon yang dapat dihubungi dan menyerahkannya kepada Petugas TPT atau Pojok Pajak/Mobil Pajak/Drop Box.

2. Petugas TPT/ Pojok Pajak/Mobil Pajak/Drop Box menerima amplop tertutup yang berisi SPT Tahunan/e-SPT Tahunan dari Wajib Pajak, termasuk dari Wajib Pajak yang tidak terdaftar di wilayah kerja KPP dimana TPT/ Pojok Pajak/Mobil Pajak/Drop Box tersebut berada, dan langsung memberikan Tanda Terima SPT tanpa didahului penelitian atas kelengkapan SPT, untuk selanjutnya diserahkan kepada Wajib Pajak.

3. KPP yang menerima SPT Wajib Pajak selain yang terdaftar di KPP tersebut, mengirimkan SPT Wajib Pajak ke KPP ditempat Wajib Pajak terdaftar paling lambat dalam jangka waktu 10 (sepuluh) hari, kecuali untuk SPT Lebih Bayar (LB) paling lambat dalam jangka waktu 3 (tiga) hari sejak SPT diterima dengan melampirkan Daftar Nominatif dan membuat Surat Pengiriman SPT per KPP tempat Wajib Pajak terdaftar.

4. KPP melakukan penelitian atas kelengkapan SPT paling lama dalam jangka waktu 2 (dua) bulan setelah SPT diterima sebagaimana dimaksud pada Pasal 5 ayat (1), kecuali untuk SPT Lebih Bayar dalam jangka waktu paling lama 14 (empat belas) hari 
kerja. Apabila berdasarkan hasil penelitian SPT Tahunan/e-SPT Tahunan dinyatakan tidak lengkap, terhadap Wajib Pajak dikirimkan Surat Permintaan Kelengkapan SPT Tahunan/e-SPT Tahunan.

5. Atas permintaan kelengkapan SPT tersebut, paling lambat 30 hari sejak tanggal Surat Permintaan Kelengkapan SPT, Wajib Pajak wajib menyampaikan kelengkapan SPT Tahunan/e-SPT Tahunan ke KPP dimana Wajib Pajak terdaftar dan menyerahkannya kepada Petugas TPT.

6. Petugas TPT menerima dan meneliti kelengkapan SPT yang diminta, selanjutnya mencetak Bukti Penerimaan Surat (BPS) dan menyerahkannya kepada Wajib Pajak.

7. Apabila sampai batas waktu 30 hari sejak tanggal Surat Permintaan Kelengkapan SPT Tahunan/e-SPT Tahunan telah terlampaui dan Wajib Pajak belum menyampaikan kelengkapan SPT, maka SPT dianggap tidak disampaikan dan kepada Wajib Pajak dikirimkan surat pemberitahuan yang menyatakan bahwa SPT Tahunan/e-SPT Tahunan dianggap tidak disampaikan. 8. Terhadap SPT yang telah dilakukan penelitian dan dinyatakan lengkap, dilakukan perekaman Tanda Terima SPT dan dilanjutkan dengan perekaman detil SPT pada aplikasi Sistem Informasi Direktorat Jenderal Pajak.

8. Jangka waktu perekaman SPT ditetapkan paling lambat 1 (satu) bulan sejak SPT Lebih Bayar (LB) diterima lengkap atau 3 (tiga) bulan sejak SPT Kurang Bayar $(\mathrm{KB}) /$ Nihil $(\mathrm{N})$ diterima lengkap.

Jenis SPT dibagi atas dua bagian yaitu :

1. SPT masa, adalah surat yang oleh wajib pajak digunakan untuk melaporkan penghitungan atau pembayaran pajak yang terutang dalam suatu masa pajak atau pada suatu saat.

2. SPT tahunan, adalah surat yang oleh wajib pajak digunakan untuk melaporkan penghitungan dan pembayaran pajak yang terutang dalam suatu tahun pajak.

Sanksi terlambat atau tidak menyampaikan SPT adalah sebagai berikut :

1. Wajib pajak terlambat menyampaikan SPT dikenakan denda untuk SPT-masa sebesar Rp. 50.000 dan untuk SPT tahunan sebesar Rp. 100.000.

2. Tidak menyampaikan SPT atau menyampaikan SPT tetapi isinya tidak benar atau tidak lengkap, atau melampirkan keterangan yang isinya tidak benar karena kealpaan wajib pajak sehingga dapat menimbulkan kerugian pada pendapatan Negara, dipidana dengan pidana penjara paling lama 6 tahun dengan denda paling tinggi 4 kali jumlah pajak terutang yang tidak atau kurang dibayar.

\section{METODE PENELITIAN}

\section{A. Jenis data}

Dalam menyusun laporan akhir ini penulis memerlukan data-data yang terbagi atas berbagai macam, meliputi :

1. Data Primer.

a. Data tentang pemberian tunjangan dan potongan dari gaji pokok.

b. Data jumlah pegawai.

2. Data Sekunder.

a. Sejarah kantor pemerintah kota Bitung

b. Bidang kerja Kantor pemerintah kotaBitung.

\section{B. Teknik Pengumpulan Data}

Sesuai dengan penelitian maka teknik yang digunakan untu memperoleh data adalah sebagai berikut :

1. Metode Pengumpulan Data 
Metode merupakan cara utama yang digunakan untuk mencapai tujuan dalam mengumpulkan data dan mengevaluasinya.Metode yang digunakan oleh penulis adalah metode pengumpulan dan analisa data.

2. Jenis Pengumpulan Data

Jenis pengumpulan data yang dilakukan untuk mengumpulkan data terdiri dari beberapa jenis yaitu:

a. Observasi (pengamatan).

Observasi ialah suatu teknik pengumpulan data dimana peneliti mengadakan pengamatan secara langsung terhadap obyek penelitian yang merupakan sumber data, sehingga data yang diperoleh benar-benar bersifat obyektif.Observasi atau pengamatan ini dilakukan di Kantor Pemerintah kotaBitung.

b. Interview (wawancara).

Interview merupakan suatu teknik pengumpulan data dimana peneliti melakukan wawancara langsung dengan obyek yang diteliti.Interview atau juga wawancara seperti halnya teknik observasi dilakukan secara bersamaan di Kantor Pemerintah kotaBitung. Dalam interview tidak lupa harus disiapkan pedoman apa yang akan ditanyakan.

c. Dokumentasi.

Dokumentasi ialah suatu teknik pengumpulan data dengan mempergunakan data-data yang ada dalam dokumen instansi.Dokumentasi data dilakukan di kantor pemerintah kota Bitung. Melalui metode ini data yang mungkin dapat diambil adalah sejarah kota bitung, letak kota Bitung, visi dan misi kota Bitung, struktur organisasi dan peta kota Bitung.

\section{Metode Analisis}

Untuk menganalisis data yang diperoleh, penulis mengadakan metode analisis data yaitu sebagai berikut :

a. Data Kuantitatif.

Metode analisa data ini dilakukan hampir bersamaan saat langsung memperoleh data, dalam metode ini diperlukan kalimat pembanding antara data yang diperoleh dengan teori yang ada di literatur sehingga informasi dari pihak instansi dapat diketahui permasalahan yang ada, apa yang menyebabkan dan bagaimana akibatnya apabila masalah tersebut tidak segera diatasi dan pencarian solusi masalah. Data yang dianalisa adalah perhitungan Pajak Penghasilan pasal 21 yang dikenakan.

b. Data Kualitatif.

Metode analisa data ini berkaitan dengan data instansi yang berupa data non angka dan data tersebut seperti contohnya adalah kebijakan dari instansi dalam penentuan besarnya gaji dan besarnya tunjangan yang diperoleh oleh pegawai.

\section{HASIL PENELITIAN DAN PEMBAHASAN}

\section{A. Hasil Penelitian}

Mekanisme penggajian oleh pemerintah kota Bitung yang dilakukan oleh kantor bagian pengelolaan keuangan yaitu dengan cara pertama diterima, masuk ke BKD gaji $80 \%$ gaji pokok dengan SK CPNS yang pada saat itu sesuai dengan peraturan menteri keuangan ditambah dengan tunjangan istri/suami $10 \%$ dan untuk anak 2\%. Kemudian berkas $80 \%$ dimasukkan dibagian keuangan pada bagian gaji dengan SK $80 \%$ yang sudah dilegalisir, kemudian bagian gaji menginput kesistem gaji. Setelah itu di print sebanyak tiga rangkap/SKPD kemudian bendahara SKPD menggajukan tagihan kebagian keuangan. Setelah itu dimasukkan keverifikasi yang kemudian diperiksa bagian keuangan setelah itu dimasukkan ke bagian pembukuan untuk diekspor kedalam system SIMDA.Kemudian masuk kebagian SP2D dibuat 1 rangkap. Rangkap pertama dibawah ke bank yang akanmelakukan pencairan direkening masing-masing pegawai. Gaji yang diberikan oleh pemerintah 
kotabitung kepada setiap pegawai, itu berdasarkan golongan, masa kerja dan tunjangan untuk setiap pegawai.

Mekanisme pemotongan pajak penghasilan PPh pasal 21 oleh pemerintah kota Bitung khususnya bagian kantor penggelolaan keuangan yaitu, pemotongan PPh pasal 21 dilakukan melalui sistem yang digunakan oleh pemerintah kota Bitung yang langsung terpotong secara otomatis untuk setiap pegawai yang berada pada masing-masing SKPD. Kemudian untuk proses penyetoran pajak penghasilan $(\mathrm{PPh})$ pasal 21 disetor melalui bank persepsi, seperti bank BRI dan BNI. Penyetoran pajak penghasilan (PPh) pasal 21 dilakukan sebelum tanggal 5 bulan yang bersangkutan, berdasarkan rekapan dibuat kwitansi sebanyak 3 rangkap, SSP $\mathrm{PPh}$ pasal 21 dibuat sebanyak 5 rangkap kemudian dimasukkan kebagian verifikasi yang diekspor ke bagian keuangan dan selanjutnya dibuatkan SP2D. Setelah SP2D diterima oleh pegawai bagian keuangan langsung disetorkan ke bank yang bersangkutan kemudian langsung di transferkan ke kas Negara.Apabila bendaharawan pemerintah terlambat menyetor dikenakan sanksi adminsitrasi berupa bunga sebesar 2\% sebulan (UU KUP Pasal 14). Untuk proses pelaporan pajak penghasilan $(\mathrm{PPh})$ pasal 21 dilaporkan pada bulan berikutnya dikantor pajak pratama (KPP) paling lambat tanggal 10 bulan yang bersangkutan dengan melampirkan SSP yang sudah disetor dan SPT masa. Apabila kewajiban tersebut tidak dilaksanakan, Wajib Pajak dikenakan sanksi administrasi berupa denda sesuai Pasal 7 UU KUP sebesar Rp. $100.000,-$ 


\section{Pembahasan}

\begin{tabular}{|c|c|c|c|c|c|c|c|c|c|c|c|c|c|c|}
\hline \multirow[b]{2}{*}{ NO } & \multirow[b]{2}{*}{$\begin{array}{c}\text { NAMA PEGAWAI } \\
\text { TANGGAL LAHIR } \\
\text { NIP } \\
\text { STATUS } \\
\text { PEGAWAI/GOLONGAN } \\
\text { NPWP }\end{array}$} & \multirow[b]{2}{*}{$\begin{array}{c}\text { STS } \\
\text { KAWIN } \\
\text { JUMLAH } \\
\text { JIWA }\end{array}$} & \multicolumn{7}{|c|}{ PENGHASILAN } & \multicolumn{4}{|c|}{ POTONGAN } & \multirow[b]{2}{*}{$\begin{array}{c}\text { JUMLAH } \\
\text { BERSIH } \\
\text { TANDA } \\
\text { TANGAN } \\
\text { NO. } \\
\text { REKENING }\end{array}$} \\
\hline & & & \multicolumn{2}{|c|}{$\begin{array}{c}\text { GAJI POKOK } \\
\text { TUNJUNGAN } \\
\text { ISTRI/SUAMI } \\
\text { TUNJANGAN ANAK } \\
\text { TPP }\end{array}$} & \multicolumn{2}{|c|}{$\begin{array}{c}\text { TUNJANGAN } \\
\text { ESELON } \\
\text { TUNJANGAN } \\
\text { UMUM } \\
\text { TUNJANGAN } \\
\text { FUNGSIONAL } \\
\text { TUNJANGAN } \\
\text { KHUSUS }\end{array}$} & \multicolumn{2}{|c|}{$\begin{array}{c}\text { TUNJANGAN } \\
\text { TERPENCIL } \\
\text { TKD } \\
\text { TUNJANGAN } \\
\text { BERAS } \\
\text { TUNJANGAN } \\
\text { PAJAK }\end{array}$} & $\begin{array}{l}\text { TUNJANGAN } \\
\text { ASKES } \\
\text { PEMBULATA } \\
\text { N } \\
\text { JUMLAH } \\
\text { KOTOR }\end{array}$ & \multicolumn{2}{|c|}{$\begin{array}{c}\text { POTONGAN } \\
\text { PAJAK } \\
\text { POTONGAN } \\
\text { ASKES } \\
\text { POTONGAN IWP } \\
10 \% \\
\text { POTNGAN } \\
\text { TAPLIUM }\end{array}$} & \multicolumn{2}{|c|}{$\begin{array}{l}\text { HUTANG/LAI } \\
\text { N-LAIN } \\
\text { BULOG } \\
\text { SEWA } \\
\text { RUMAH } \\
\text { POTONGAN }\end{array}$} & \\
\hline 1 & $\begin{array}{l}\text { IVONNE S. MANGKEY, } \\
\text { SE }\end{array}$ & TK-0 & $\mathrm{Rp}$ & $2,255,200$ & $\mathrm{Rp}$ & - & $\mathrm{Rp}$ & - & $\mathrm{Rp}$ & $\mathrm{Rp}$ & 12,616 & $\mathrm{Rp}$ & - & $\mathrm{Rp} 2,277,500$ \\
\hline & 08 Februari 1982 & 0 & $\mathrm{Rp}$ & - & $\mathrm{Rp}$ & 185,000 & $\mathrm{Rp}$ & - & $\mathrm{Rp}$ & $\mathrm{Rp}$ & - & $\mathrm{Rp}$ & - & \\
\hline & 198208022010012000 & 1 & $\mathrm{Rp}$ & - & $\mathrm{Rp}$ & - & $\mathrm{Rp}$ & 69,760 & Rp 2,522,636 & $\mathrm{Rp}$ & 225,520 & $\mathrm{Rp}$ & - & \\
\hline & (PNS-3A) MKG : 2 & & $\mathrm{Rp}$ & - & $\mathrm{Rp}$ & - & $\mathrm{Rp}$ & 12,616 & $\mathrm{Rp}$ & $\mathrm{Rp}$ & 7,000 & $\mathrm{Rp}$ & 245,136 & \\
\hline & 15.412.428.3-821.00 & & & & & & & & & & & & & \\
\hline 2 & $\begin{array}{l}\text { IVONNE S. MANGKEY, } \\
\text { SE }\end{array}$ & K- 1 & $\mathrm{Rp}$ & $2,424,700$ & $\mathrm{Rp}$ & - & $\mathrm{Rp}$ & - & $\mathrm{Rp}$ & $\mathrm{Rp}$ & 20,208 & $\mathrm{Rp}$ & - & $\mathrm{Rp} 2,944,800$ \\
\hline & 08 Februari 1982 & 2 & $\mathrm{Rp}$ & 242,470 & $\mathrm{Rp}$ & 185,000 & $\mathrm{Rp}$ & - & $\mathrm{Rp}$ & $\mathrm{Rp}$ & - & $\mathrm{Rp}$ & - & \\
\hline & 198208022010012000 & 4 & $\mathrm{Rp}$ & 96,988 & $\mathrm{Rp}$ & - & $\mathrm{Rp}$ & 279,040 & $\mathrm{Rp} 3,248,423$ & $\mathrm{Rp}$ & 276,415 & $\mathrm{Rp}$ & - & \\
\hline & (PNS-3B) MKG : 4 & & $\mathrm{Rp}$ & - & $\mathrm{Rp}$ & - & $\mathrm{Rp}$ & 20,208 & $\mathrm{Rp}$ & $\mathrm{Rp}$ & 7,000 & $\mathrm{Rp}$ & 303,623 & \\
\hline & $15.412 .428 .3-821.00$ & & & & & & & & & & & & & \\
\hline
\end{tabular}




\section{Perhitungan Pemotongan Pajak Penghasilan Pasal 21 Pada Pegawai Menurut Pemerintah Kota Bitung}

Tabel 4.4 Perhitungan pemotongan pajak penghasilan PPh pasal 21 dilakukan oleh pemerintah atas gaji pegawai melalui peraturan-peraturan yang berlaku, yaitu sebagai berikut :

Gaji pokok

Tunjangan istri/suami $\quad 10 \%$

Tunjangan anak 2

$2 \%$
Jumlah gaji \& tunjangan

Tunjangan 2

pembulatan

Tunjangan beras

56.560

4 jiwa

2.066 .000

206.600

82.640

2.355 .240

540.000

84

Tunjangan gaji \& tunjangan kotor

3.064 .524

Pengurangan

Biaya jabatan dr bruto

$$
\text { 5\% Max }
$$

500.0

00

153.226

Iuran pensiun dari

GATUN

$4,75 \% \mathrm{Max}$

200.0

00

111.874

265.100

Jumlah pengurang

Jumlah penghasilan

netto/bln

Jumlah penghasilan

netto/thn

33.593 .087

PTKP

Pribadi

15.840 .000

Kawin

1.320 .000

Anak 2

2.640 .000

Jumlah PTKP

19.800 .000

Jumlah penghasilan

kena pajak

13.793.087 
Tarif 5\%

Per bulan
689.654 S/D 50

juta

57.471

Sumber data : kepala bagian pengelolaan keuangan

Tabel 4.4 menunjukkan daftar gaji pokok pegawai pemerintah kota bitung serta tunjangan yang diberikan kepada setiap pegawai yang ada sesuai dengan golongan. Yang kemudian akan dipotong pajak penghasilan setiap bulan.

Tabel 4.5 Rekapitulasi penerimaan PPh pasal 21 berdasarkan golongan yang ada selama satu tahun yaitu sebagai berikut :

\begin{tabular}{|c|c|c|c|c|c|c|}
\hline \multirow{2}{*}{$\begin{array}{c}\text { BULAN } \\
\text { JANUARI }\end{array}$} & \multirow{2}{*}{$\begin{array}{c}\text { GOLONGAN } \\
\text { GOLONGAN IV } \\
\end{array}$} & \multirow{2}{*}{$\begin{array}{c}\begin{array}{c}\text { JUMLAH } \\
\text { PEGAWAI }\end{array} \\
880 \\
\end{array}$} & \multicolumn{2}{|c|}{$\begin{array}{l}\text { PENERIMAAN } \\
\text { PPH PASAL } 21\end{array}$} & \multicolumn{2}{|c|}{ TOTAL } \\
\hline & & & $\mathrm{Rp}$. & $80,404,610$ & & \\
\hline & GOLONGAN III & 2,125 & $\mathrm{Rp}$ & $107,520,248$ & & \\
\hline & GOLONGAN II & 949 & $\mathrm{Rp}$ & $19,355,631$ & & \\
\hline & GOLONGAN I & 31 & $\mathrm{Rp}$ & 282,693 & & \\
\hline & INSIDENTIL & & $\mathrm{Rp}$ & 203,118 & & \\
\hline & & & & & $\mathbf{R p}$ & $207,766,300$ \\
\hline \multirow[t]{6}{*}{ FEBRUARI } & GOLONGAN IV & 900 & $\mathrm{Rp}$ & $82,135,042$ & & \\
\hline & GOLONGAN III & 2,137 & $\mathrm{Rp}$ & $107,555,293$ & & \\
\hline & GOLONGAN II & 920 & $\mathrm{Rp}$ & $18,804,169$ & & \\
\hline & GOLONGAN I & 21 & $\mathrm{Rp}$ & 243,126 & & \\
\hline & INSIDENTIL & & $\mathrm{Rp}$ & $4,923,866$ & & \\
\hline & & & & & $\mathbf{R p}$ & $213,661,496$ \\
\hline \multirow[t]{6}{*}{ MARET } & GOLONGAN IV & 904 & $\mathrm{Rp}$ & $82,645,860$ & & \\
\hline & GOLONGAN III & 2,254 & $\mathrm{Rp}$ & $108,984,984$ & & \\
\hline & GOLONGAN II & 1,009 & $\mathrm{Rp}$ & $19,046,549$ & & \\
\hline & GOLONGAN I & 21 & $\mathrm{Rp}$ & 247,047 & & \\
\hline & INSIDENTIL & & $\mathrm{Rp}$ & $2,634,477$ & & \\
\hline & & & & & $\mathbf{R p}$ & $213,558,917$ \\
\hline \multirow[t]{6}{*}{ APRIL } & GOLONGAN IV & 904 & $\mathrm{Rp}$ & $99,266,529$ & & \\
\hline & GOLONGAN III & 2,250 & $\mathrm{Rp}$ & $136,027,728$ & & \\
\hline & GOLONGAN II & 1,014 & $\mathrm{Rp}$ & $27,395,423$ & & \\
\hline & GOLONGAN I & 21 & $\mathrm{Rp}$ & 421,936 & & \\
\hline & INSIDENTIL & & $\mathrm{Rp}$ & $3,028,965$ & & \\
\hline & & & & & $\mathbf{R p}$ & $266,140,581$ \\
\hline \multirow[t]{4}{*}{ MEI } & GOLONGAN IV & 900 & $\mathrm{Rp}$ & $98,878,538$ & & \\
\hline & GOLONGAN III & 2,249 & $\mathrm{Rp}$ & $136,105,054$ & & \\
\hline & GOLONGAN II & 1,009 & $\mathrm{Rp}$ & $27,283,103$ & & \\
\hline & GOLONGAN I & 20 & $\mathrm{Rp}$ & 408,112 & & \\
\hline
\end{tabular}




\begin{tabular}{|c|c|c|c|c|c|c|}
\hline & INSIDENTIL & & $\mathrm{Rp}$ & 590,538 & & \\
\hline & & & & & $\mathbf{R p}$ & $263,265,345$ \\
\hline \multirow[t]{6}{*}{ JUNI } & GOLONGAN IV & 897 & $\mathrm{Rp}$ & $98,563,656$ & & \\
\hline & GOLONGAN III & 2,286 & $\mathrm{Rp}$ & $141,466,110$ & & \\
\hline & GOLONGAN II & 970 & $\mathrm{Rp}$ & $26,854,822$ & & \\
\hline & GOLONGAN I & 20 & $\mathrm{Rp}$ & 410,082 & & \\
\hline & INSIDENTIL & & $\mathrm{Rp}$ & $4,173,344$ & & \\
\hline & & & & & $\mathbf{R p}$ & $271,468,014$ \\
\hline JULI & GOLONGAN IV & 897 & $\mathrm{Rp}$ & $98,533,992$ & & \\
\hline
\end{tabular}

\begin{tabular}{|c|c|c|c|c|c|c|}
\hline & GOLONGAN III & 2,293 & $\mathrm{Rp}$ & $142,097,274$ & & \\
\hline & GOLONGAN II & 953 & $\mathrm{Rp}$ & $26,405,259$ & & \\
\hline & GOLONGAN I & 20 & $\mathrm{Rp}$ & 413,691 & & \\
\hline & INSIDENTIL & & $\mathrm{Rp}$ & $3,977,485$ & & \\
\hline & & & & & $\mathbf{R p}$ & $271,427,701$ \\
\hline \multirow[t]{6}{*}{ AGUSTUS } & GOLONGAN IV & 905 & $\mathrm{Rp}$ & $99,045,697$ & & \\
\hline & GOLONGAN III & 2,280 & $\mathrm{Rp}$ & $142,203,430$ & & \\
\hline & GOLONGAN II & 949 & $\mathrm{Rp}$ & $26,305,400$ & & \\
\hline & GOLONGAN I & 20 & $\mathrm{Rp}$ & 413,691 & & \\
\hline & INSIDENTIL & & & & & \\
\hline & & & & & $\mathbf{R p}$ & $267,968,218$ \\
\hline \multirow[t]{6}{*}{ SEPTEMBER } & GOLONGAN IV & 912 & $\mathrm{Rp}$ & $99,751,174$ & & \\
\hline & GOLONGAN III & 2,265 & $\mathrm{Rp}$ & $140,961,084$ & & \\
\hline & GOLONGAN II & 948 & $\mathrm{Rp}$ & $26,323,135$ & & \\
\hline & GOLONGAN I & 20 & $\mathrm{Rp}$ & 418,566 & & \\
\hline & INSIDENTIL & & $\mathrm{Rp}$ & $4,324,344$ & & \\
\hline & & & & & $\mathbf{R p}$ & $271,778,303$ \\
\hline \multirow[t]{6}{*}{ OKTOBER } & GOLONGAN IV & 908 & $\mathrm{Rp}$ & $99,350,281$ & & \\
\hline & GOLONGAN III & 2,261 & $\mathrm{Rp}$ & $140,715,863$ & & \\
\hline & GOLONGAN II & 947 & $\mathrm{Rp}$ & $26,318,465$ & & \\
\hline & GOLONGAN I & 20 & $\mathrm{Rp}$ & 420,795 & & \\
\hline & INSIDENTIL & & $\mathrm{Rp}$ & $1,109,118$ & & \\
\hline & & & & & $\mathbf{R p}$ & $267,914,522$ \\
\hline \multirow[t]{6}{*}{ NOVEMBER } & GOLONGAN IV & 908 & $\mathrm{Rp}$ & $99,393,523$ & & \\
\hline & GOLONGAN III & 2,254 & $\mathrm{Rp}$ & $140,286,666$ & & \\
\hline & GOLONGAN II & 946 & $\mathrm{Rp}$ & $26,290,268$ & & \\
\hline & GOLONGAN I & 19 & $\mathrm{Rp}$ & 390,499 & & \\
\hline & INSIDENTIL & & & & & \\
\hline & & & & & $\mathbf{R p}$ & $266,360,956$ \\
\hline DESEMBER & GOLONGAN IV & 908 & $\mathrm{Rp}$ & $99,505,207$ & & \\
\hline
\end{tabular}




\begin{tabular}{|r|c|c|cr|rr|} 
& GOLONGAN III & 2,253 & $\mathrm{Rp}$ & $140,706,892$ & & \\
\hline & GOLONGAN II & 943 & $\mathrm{Rp}$ & $26,313,619$ & & \\
\hline & GOLONGAN I & 19 & $\mathrm{Rp}$ & 390,499 & & \\
\hline & INSIDENTIL & & $\mathrm{Rp}$ & 55,124 & & \\
\hline & & & & $\mathbf{R p}$ & $\mathbf{2 6 6 , 9 7 1 , 3 4 1}$ \\
\hline & & & & $\mathbf{R p}$ & $\mathbf{3 , 0 4 8 , 2 8 1 , 6 9 4}$ \\
\hline
\end{tabular}

Tabel 4.5 Rekapitulasi penerimaan pemotongan PPh pasal 21 berdasarkan bulan, sebagai berikut :

\begin{tabular}{|c|c|rc|}
\hline NO & BULAN & \multicolumn{2}{|c|}{ TOTAL } \\
\hline 1 & JANUARI & $\mathrm{Rp}$ & $207,766,300$ \\
\hline 2 & FEBRUARI & $\mathrm{Rp}$ & $213,661,496$ \\
\hline 3 & MARET & $\mathrm{Rp}$ & $213,558,917$ \\
\hline 4 & $\mathrm{APRIL}$ & $\mathrm{Rp}$ & $266,140,581$ \\
\hline 5 & $\mathrm{MEI}$ & $\mathrm{Rp}$ & $263,265,345$ \\
\hline 6 & $\mathrm{R} p$ & $271,468,014$ \\
\hline 7 & $\mathrm{JUNI}$ & $\mathrm{Rp}$ & $271,427,701$ \\
\hline 8 & AGUSTUS & $\mathrm{Rp}$ & $267,968,218$ \\
\hline 9 & SEPTEMBER & $\mathrm{Rp}$ & $271,778,303$ \\
\hline 10 & OKTOBER & $\mathrm{Rp}$ & $267,914,522$ \\
\hline 11 & NOVEMBER & $\mathrm{Rp}$ & $266,360,956$ \\
\hline 12 & DESEMBER & $\mathrm{Rp}$ & $266,971,341$ \\
\hline \multicolumn{2}{|c|}{ JUMLAH PENERIMAAN PPH PASAL $\mathbf{2 1}$} \\
\multicolumn{3}{|c|}{ Rp } \\
\multicolumn{2}{|c|}{ SELAMA SATU TAHUN } \\
\hline
\end{tabular}

Sumber Data : Kantor Pengelolaan Keuangan

Rekapitulasi pemotongan $\mathrm{PPh}$ pasal 21 dihitung berdasarkan data yang diperoleh dari pemerintah kota Bitung khususnya pada kantor bagian pengelolaan keuangan daerah yang ada. Di lihat dari tabel yang berada diatas, Untuk penerimaan pemotongan pajak penghasilan secara keseluruhan selama satu tahun oleh pemerintah kota Bitung berjumlah Rp. 3.048.281.694 dan langsung disetorkan ke kas Negara.

\section{G. Evaluasi Hasil Penelitian}

Setelah melakukan proses penelitian di kantor pemerintah kota Bitung sesuai dengan judul yang diangkat untuk laporan akhir, dapat dilihat sudah sesuai dengan prosedur yang berlaku sehingga tidak ada masalah yang ditemui selama proses perhitungan, pemotongan, dan pelaporan. Karena dimana untuk mekanisme mulai dari perhitungan, pemotongan sampai pada pelaporan sudah dilakukan berdasarkan peraturan-peraturan yang berlaku sehingga sampai saat ini untuk proses laporannya ke kantor perpajakan tidak ada masalah karena dilakukan setiap bulan oleh pemerintah kota bitung. Ini berdasarkan evaluasi yang didapatkan dari pihak pemerintah dan juga dari hasil penelitian yang sudah dilakukan dan juga sudah dilakukan proses perhitungan, pemotongan dan pelaporan berdasarkan data yang diperoleh dari pemerintah kota Bitung.

Berikut adalah analisa yang dilakukan untuk mekanisme penyetoran dan pelaporan pajak penghasilan PPh pasal 21 berdasarkan hasil penelitian yang dilakukan. 
1. Prosedur perhitungan pajak penghasilan dilakukan berdasarkan SK walikota yang kemudian melampirkan surat pengantar dari dinas yang bersangkutan diberikan kepada secretariat badan penggelolaan keuangan setelah itu disposisi ke bagian perbendaharaan khusus pada bagian gaji, berdasarkan SK bagian gaji membuat perubahan pada sistem gaji sehingga pajak penghasilan akan terpotong secara otomatis.

2. Proses penyetoran pajak penghasilan $(\mathrm{PPh})$ pasal 21 disetor melalui bank persepsi, seperti bank BRI dan BNI. Penyetoran pajak penghasilan pasal 21 dilakukan sebelum tanggal 5 bulan yang bersangkutan, berdasarkan rekapan dibuat kwitansi sebanyak 3 rangkap, SSP PPh pasal 21 dibuat sebanyak 5 rangkap kemudian dimasukkan kebagian verifikasi yang diekspor ke bagian keuangan dan selanjutnya dibuatkan SP2D. Setelah SP2D diterima oleh pegawai bagian keuangan langsung disetorkan ke bank yang bersangkutan kemudian langsung di transferkan ke kas Negara. Apabila bendaharawan pemerintah terlambat menyetor dikenakan sanksi adminsitrasi berupa bunga sebesar 2\% sebulan (UU KUP Pasal 14).

3. Untuk proses pelaporan pajak penghasilan pasal 21 dilaporkan pada bulan berikutnya dikantor pajak pratama (KPP) paling lambat tanggal 10 bulan yang bersangkutan dengan melampirkan SSP yang sudah disetor dan SPT masa. Apabila kewajiban tersebut tidak dilaksanakan, Wajib Pajak dikenakan sanksi administrasi berupa denda sesuai Pasal 7 UU KUP sebesar Rp. 100.000,-

Berdasarkan proses pemotongan $\mathrm{PPh}$ pasal 21 atas gaji pegawai pemerintah kota Bitung, tidak terdapat kesalahan karena prosedur yang dilaksanakan sesuai dengan peraturan yang ada dan sudah sangat efektif karena sudah menggunakan system yang dipakai oleh pemerintah kota Bitung. Dimana untuk proses perhitungan dan pelaporan itu dilakukan setiap bulan dan secara otomatis langsung dipotong dari gaji pegawai yang ada, yang kemudian langsung disetorkan ke bank yang menjadi persepsi atau bank yang bersangkutan.

Dengan penelitian ini penulis melakukan perbandingan antara teori dengan hasil penelitian yang didapatkan lewat pemerintah kota Bitung.

Tabel 4.6 Perbandingan Teori Dengan Hasil Penelitian Untuk Pajak Penghasilan Pasal 21 Pada

\begin{tabular}{|c|c|c|c|}
\hline \multicolumn{4}{|c|}{ Pemerintah Kota Bitung } \\
\hline $\mathrm{NO}$ & TEORI & HASIL PENELITIAN & PEMBAHASAN \\
\hline 1 & $\begin{array}{c}\text { PERPAJAKAN EDISI } \\
\text { REVISI } 2011 \\
\text { Prof. Dr. Mardiasmo, } \\
\text { MBA,Ak. } \\
\text { Tentangpajak penghasilan } \\
\text { pasal } 21 \text { dalam hal ini } \\
\text { pemotong pajak, wajib pajak, } \\
\text { objek pajak. }\end{array}$ & $\begin{array}{c}\text { Hasil penelitian yang } \\
\text { telah dilakukan pada } \\
\text { pemerintah Kota Bitung } \\
\text { untuk prosedur } \\
\text { perhitungan dan } \\
\text { pelaporan pajak } \\
\text { penghasilan pasal } 21 \\
\text { dilakukan oleh bendahara } \\
\text { daerah (pemotong pajek) } \\
\text { sudah sesuai dengan teori } \\
\text { yang ada. }\end{array}$ & $\begin{array}{l}\text { Berdasarkan teori dan hasil } \\
\text { penelitian yang telah } \\
\text { dilakukan oleh penulis tidak } \\
\text { ada perbedaan antara teori } \\
\text { dengan hasil penelitian yang } \\
\text { sudah dilakukan pada } \\
\text { pemerintah Kota Bitung, } \\
\text { karena pemerintah telah } \\
\text { melakukan pemotongan PPh } \\
\text { pasal } 21 \text { sesuai dengan } \\
\text { peraturan perpajakan. }\end{array}$ \\
\hline 2 & Proses penyetoran, dilakukan & $\begin{array}{l}\text { Pemerintah Kota Bitung } \\
\text { untuk proses penyetoran } \\
\text { telah dilakukan setiap }\end{array}$ & $\begin{array}{c}\text { Dilihat dari teori dan hasil } \\
\text { penelitian untuk proses } \\
\text { penyetoran pajak penghasilan }\end{array}$ \\
\hline
\end{tabular}




\begin{tabular}{|c|c|c|c|}
\hline & $\begin{array}{c}\text { pada setiap tanggal } 10 \text { bulan } \\
\text { berikutnya setelah masa } \\
\text { pajak berakhir. }\end{array}$ & $\begin{array}{c}\text { tanggal } 10 \text { bulan } \\
\text { berikutnya pada bank } \\
\text { persepsi dan langsung } \\
\text { dimasukan pada kas } \\
\text { Negara. }\end{array}$ & $\begin{array}{l}\text { pasal } 21 \text { yang telah dilakukan } \\
\text { oleh pemerintah Kota Bitung } \\
\text { itu sudah berdasarkan } \\
\text { petunjuk dari peraturan } \\
\text { perpajakan, sehingga proses } \\
\text { penyetorannya dilakukan } \\
\text { padas setiap tanggal } 10 \text { bulan } \\
\text { berikutnya dan disetor } \\
\text { langsung oleh bendahara } \\
\text { daerah yang ada pada bagian } \\
\text { pengelolaan keuangan }\end{array}$ \\
\hline 3 & $\begin{array}{l}\text { www.pajak.go.id } \\
\text { Proses pelaporan pajak } \\
\text { penghasilan pasal } 21, \\
\text { dilakukan paling lama } 20 \\
\text { hari sebelum masa pajak } \\
\text { berakhir, dengan mengisi } \\
\text { formulir pajak yang ada. }\end{array}$ & $\begin{array}{l}\text { Untuk proses pelaporan } \\
\text { PPh pasal } 21 \\
\text { dilingkungan pemerintah } \\
\text { Kota Bitung sesuai } \\
\text { dengan teori dan } \\
\text { petunjuk dari dirjen pajak } \\
\text { yaitu pelaporannya } \\
\text { dilakukan paling lama } \\
\text { setiap } 20 \text { hari setelah } \\
\text { masa pajak berakhir. } \\
\text { Dengan melampirkan } \\
\text { bukti penyetoran yang } \\
\text { sudah dilakukan. }\end{array}$ & $\begin{array}{c}\text { Dari hasil teori dan hasil } \\
\text { penelitaian pemerintah Kota } \\
\text { Bitung untuk proses } \\
\text { pelaporan } \mathrm{PPh} \text { pasal } 21 \\
\text { dilakukan pada kantor } \\
\text { perpajakan dengan } \\
\text { melampirkan SSP dan SPT } \\
\text { masa yang sudah disetor. } \\
\text { Sehingga untuk proses } \\
\text { pelaporannya yang sudah } \\
\text { dilakukan oleh pemerintah } \\
\text { selalu tepat pada waktunya } \\
\text { dengan berdasarkan atas } \\
\text { peraturan-peraturan yang ada. }\end{array}$ \\
\hline
\end{tabular}

\section{KESIMPULAN DAN SARAN}

\section{A. Kesimpulan}

Dari hasil penelitian dan pembahasan maka dapat di simpulkan beberapa kesimpulan sebagai berikut :

1. Dilihat dari hasil penelitian yang dilakukan untuk proses perhitungan PPH pasal 21 yang dilakukan oleh pemerintah kota Bitung atas gaji pegawai dengan gaji bulanan pemerintah telah melakukan sesuai dengan ketentuan perpajakan. Pemerintah kota Bitung telah melakukan kewajiban untuk menghitung dan memotong serta melaporkan PPh pasal 21 tepat pada waktunya dan dilakukan penghitungan setiap bulan.

2. Dalam melakukan kewajiban penyetoran setiap bulannya, pemerintah kota Bitung telah menyetorkan PPH pasal 21 masa tepat pada waktunya. Berdasarkan ketentuan perpajakan, pemerintah kota Bitung wajib menyetorkan PPH pasal 21 yang telah dipotong dari gaji pegawai pada setiap bulan. Jika pemerintah kota Bitung tidak melakukan penyetoran setiap bulan maka akan dikenakan sanksi atau denda sebesar $2 \%$. 
3. Pemerintah kota Bitung sebagai pemotong pajak juga wajib melaporkan penyetoran pajak penghasilan pasal 21 masa yang telah dilakukan. Dalam hal ini pemerintah kota Bitung telah melakukan pelaporan pajak penghasilan pasal 21 masa tepat pada waktunya atau setiap tanggal 10 bulan yang bersangkutan.

4. Berdasarkan penghitungan ulang yang dilakukan oleh pemerintah kota Bitung pada setiap akhir tahun dalam hal ini melakukan rekapitulasi pemasukan PPH pasal 21 tahunan berjumlah Rp. 3.048.281.694 dan jumlah ini sudah disetorkan langsung ke kas Negara.

\section{B. Saran}

Berdasarkan dari kesimpulan yang telah dikemukakan maka penulis mengajukan beberapa saran sebagai berikut :

1. Pemerintah kota Bitung sebaiknya harus memahami tentang kewajiban penghitungan, pemotongan, dan pelaporan PPH pasal 21 masa menggingat ketentuan perpajakan kadang selalu mengalami perubahan dari tahun ke tahun.

2. Pemerintah kota Bitung juga harus lebih lagi memperdalam mengenai PPh pasal 21 atau pemerintah melakukan sosialisasi kepada setiap SKPD mengenai proses pemotongan, penyetoran, dan pelaporan yang dilakukan setiap bulan atas gaji pegawai sehingga setiap pegawai tidak akan ketinggalan informasi mengenai peraturan perpajakan yang ada.

3. Pemerintah kota Bitung sebaiknya lebih lagi teliti untuk ketentuan penyetoran yang dilakukan sehingga terhindar dari sanksi seperti denda bunga yang akan diterima, karena hal tersebut merupakan pemborosan sumber daya pemerintah yang ada.

\section{DAFTAR PUSTAKA}

Gunadi. 2002. Ketentuan Dasar Pajak Penghasilan, Jakarta, Salemba 4.

Tjahjono, Achmad dan M. Fakhri Husein. 1999. Perpajakan, Yogyakarta, Akademi Manajemen perusahaan YKPN.

Pandiangan, Liberti. 2010. Pedoman Praktis Penghitungan Pajak Penghasilan Pasal 21 dan pasal 26, Jakarta, Salemba 4.

Mardiasmo. Perpajakan Edisi Revisi 2006, Yogyakarta, Andi.

Nazir, Muhammad.1999. Metode Penelitian, Jakarta, Ghalia Indonesia.

Mardiasmo, Perpajakan Edisi 2011, Yogyakarta. Andi

Surat Edaran Direktur Jenderal Pajak, Nomor: 24/PJ/2009, Tanggal: 27 Februari 2009 Departemen Keuangan Republik Indonesia. Direktorat Jenderal Pajak. Peraturan Jenderal Pajak Nomor : PER- 31/PJ/2009 (n.d). Pedoman Teknis Tata Cara Pemotongan, Penyetoran dan Pelaporan Pajak Penghasilan Pasal 21 dan/atau pajak Penghasilan Pasal 26 sehubungan dengan Pekerjaan, Jasa, dan Kegiatan Orang Pribadi. 26 Mei 2009. http://www.pajak.go.id/peraturan

Undang-Undang Republik Indonesia Nomor 36 Tahun 2008 Tentang Perubahan Keempat Atas UU No. 7 Tahun 1983 Tentang Pajak Penghasilan. 2010Undang-undang republic Indonesia nomor 28 tahun 2007 tentang perpajakan

Undang-Undang Republik Indonesia nomor 16 tahun 2009 dan Peraturan Menteri Keuangan RI Tahun 2013 Tentang Perpajakan 
Jakarta : Departemen Keuangan Republik Indonesia. 2007. Petunjuk Pengisian Surat Pemberitahuan Tahunan Pajak Penghasilan Wajib Pajak Orang Pribadi (SPT Tahunan PPh WP Orang Pribadi).

Jakarta :Departemen Keuangan Republik Indonesia 2009. Petunjuk Pengisian Surat Pemberitahuan Tahunan Pajak PenghasilanWajib Pajak Orang Pribadi (SPT Tahunan PPh WP Orang Pribadi).

Achmad, Fatimah. 2009. Tugas Akhir Evaluasi Pemahaman Pengisian SPT WP Orang Pribadi dengan Menggunakan Formulir 1770, 1770S, 1770SS ( Studi pada KP2KPSRAGEN). Surakarta: Universitas Sebelas Maret.

Mardiasmo. 2008. Perpajakan Edisi Revisi 2008. Yogyakarta: Andi Offset.

Peraturan Menteri Keuangan Republik Indonesia Nomor 250/Pmk.03/2008. BesarnyaBiaya Jabatan atau Biaya Pensiun yang Dapat Dikurangkan dari PenghasilanBruto Pegawai Tetap atau Pensiunan.

Peraturan Menteri Keuangan Republik Indonesia Nomor 252/PMK.03/2008. PetunjukPelaksanaan Pemotongan Pajak atas Penghasilan Sehubungan denganPekerjaan, Jasa, dan Kegiatan Orang Pribadi.

Suandy, Erly. 2002. Hukum Pajak. Jakarta : Salemba Empat.

Undang-Undang Republik Indonesia Nomor 28 Tahun 2007 Perubahan Ketiga atasUndangUndang Nomor 6 Tahun 1983. Ketentuan Umum dan Tata CaraPerpajakan.

Undang-Undang Republik Indonesia Nomor 36 Tahun 2008 Perubahan Keempat atas UndangUndang Nomor 7 Tahun 1983. Pajak Penghasilan. 